\title{
Nanomaterials for Construction Engineering-A Review
}

\author{
B. B. Das and Arkadeep Mitra
}

\begin{abstract}
Nanotechnology is not new and is known to exist for ages, be it in the sword of tipu sultan or in the windows of the medieval churches in Europe. A common question in the minds of all of us living in today's world is about how the mechanism of nanotechnology can be used in the healthy compatibility with the constructional structures like that of massive buildings and bridges, which have been thought to encroach upon huge masses of land, leading to the destroying of homes of wildlife and putting pressure in the limited reserves of energy. This review paper focuses on the sustainable usage of nano based materials like carbon nanotube, electrochromic windows, nanoclays, sandvik nanoflex ${ }^{\mathrm{TM}}$, nanowires, titanium dioxide, nanoceramic coating, nanocrystalline materials, nanosilica, nanocomposites, MMFX2 steel, nanometals, nanofibres, nanomyte ${ }^{\mathrm{TM}}$ mend MW, nanocement, which could be used for providing singular or multiple functions of potential reinforcement, corrosion resistance, insulation, fire protection, temperature resistance, reducing air conditioning loads, pollution control, UV ray absorption, lighting, when used as a part of building materials.
\end{abstract}

Index Terms-Nanotechnology, construction, materials.

\section{INTRODUCTION}

Nanotechnology concerns with the usage of materials falling in range of few to less than 100 nanometers [1]. Constructional structures form a very important part while contributing to the GDP of any economy by rendering services ranging from transportation to living to producing useful products to earning livelihood, and at the same time also commanding a very dominant share of the energy produced for utilization, no wonder that it has been estimated by a certain source that construction industry involving nanotechnology will occupy the eighth position out of the ten, having an impact on the world's development [2]. The usage of nanotechnology materials while being incorporated in constructional structures would not only help in prolonging their lifetime, but would also keep a check on the energy spent by them and at the same time gauging their reactions and reacting to different agents like fire, corrosion, water penetration, fractures, cracks, etc. Hence the literature segment of this review paper provides a list of nano-materials that can be used for these varied tasks.

\section{CARbon NANOtubes}

Laser ablation, chemical vapor deposition, electric arc processes are some of the methodologies employed for the

Manuscript received June 4, 2013; revised August 6, 2013.

B. B. Das is with National Institute of Construction Management and Research (NICMAR), Farmagudi (Ponda), Goa, India (e-mail:bibhutibhusan@gmail.com, bdas@nicmar.ac.in).

Arkadeep Mitra was with KIIT Deemed University, Bhubaneswar, Odisha, India (e-mail:arkadeep123mitra@gmail.com). production of NT's (nanotubes) that exist as metals or semiconductors. Exhibiting $\mathrm{sp}^{2}$ hybridization with walls of graphene held together in hexagonal arrays by van-der-waal force of a cylindrical honey comb like structure of an allotrope of carbon, gives a succinct definition of the carbon nanotubes (CNT's). High conductivity (being more than copper), elastic deformability, strength (being stronger than steel), surface chemistry, high stability are some of the properties that CNT's provide due to their structure and topology and is presented in Table I. A small change, in the nanometer diameter and that in the chiral and achiral nature brings different properties in that of SWCNT's (single walled carbon nanotubes), which comprises of single cylinder whereas that of MWCNT's (multi walled carbon nanotubes) comprises of multiple cylinders. Increasing the strength for a longer duration of time and prolonging life along with giving boost to the compressive strength and contributing to the tensile strength by improving the flexural strength is reported from earlier research work, when CNT's are mixed with asphalt and concrete. The stress-strain relationship of the carbon nanotubes is presented in Fig. 1. A reduction in the emission of greenhouse gases, energy consumption, maintenance costs, resistance to moisture are some of the advantages of using asphalt containing nanoparticles [3]-[19].

TABLE I: THE PROPERTIES OF CNT'S

\begin{tabular}{|c|c|}
\hline Name of the property & Characteristics \\
\hline Length to diameter ratio & 60 (SWCNT's) \\
\hline Surface area & $\sim 300 \mathrm{~m}^{2} / \mathrm{gm}$ (SWNT's) \\
\hline Density & Less $\left(2.60 \mathrm{~g} / \mathrm{cm}^{3}\right.$ for MWNT's) \\
\hline Thermal conductivity & $350 \mathrm{~K}-8 \mathrm{~K}$ (SWCNT's) \\
\hline Elongation & $\begin{array}{l}100 \% \text { (CNT based interconnects } \\
\text { which are stretchable) }\end{array}$ \\
\hline Young's Modulus & $\begin{array}{c}1.25 \mathrm{TPa} \text { (SWCNT's), } 0.9 \mathrm{TPa} \\
\text { (MWCNT's) }\end{array}$ \\
\hline Poission's Ratio & $0.06-0.55$ (SWCNT's) \\
\hline Tensile strength & $\begin{array}{l}\text { 75 GPa (SWCNT's) }<60 \mathrm{GPa} \\
\text { (MWCNT's) }\end{array}$ \\
\hline Compressive strength & $100-150 \mathrm{GPa}$ (MWCNT's) \\
\hline
\end{tabular}
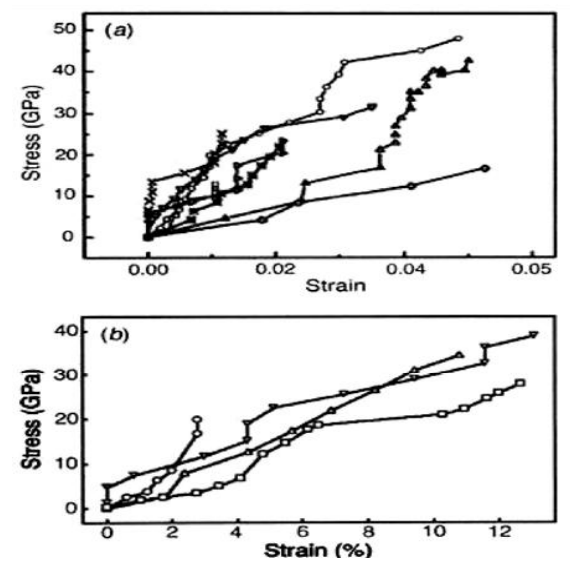

Fig. 1. Stress stain relationships of carbon nanotubes 


\section{ELECTROCHROMIC WINDOWS}

Gauging the intensity of light during alternate hours of darkness and sunlight transparency characteristics to the window are provided when removal of ions takes place due to application of high voltage and transmittance characteristics to the windows are provided with the release of chromogens and ions at low voltage due to different chromogen colors present in the tungsten oxide that acts as the electrochromic layer, from the valence band of the nickel oxide electrons escapes and the electrons jump to the W $5 \mathrm{~d}$ states of tungsten oxide when a charge is applied, thereby helping in the color changing process to take place, capacitance is provided by the counter electrode and porous semiconductor containing working electrode is separated by the insulator layer, conducting oxides (such as $\ln _{2} \mathrm{O}_{3}$ : Sn) layer are sandwiched between two layers of glass that constitute the electrochromic windows. Between the layers of conducting oxides are squeezed more three central layers [20]-[23]. The room is bought to alternate dimness (opaque) and alternate brightness (transparency) by the mode of switch and intelligent control system, which constitutes the operation of these windows. Due to the mode of working the following chemical reactions [20] takes place:

$$
\begin{gathered}
\mathrm{WO}_{3}(\text { clear })+x \mathrm{M}^{+}+x \mathrm{e}^{-} \Rightarrow \mathrm{M}_{x} \mathrm{WO}_{3}(\text { deepblue })\left(\mathrm{M}=\mathrm{H}, \mathrm{L}_{\mathrm{i}}\right) \\
\mathrm{NiO}(\text { clear })+x \mathrm{OH} \Rightarrow \mathrm{NiO}(\mathrm{OH})_{X}(\text { gray })+x \mathrm{e}^{-}
\end{gathered}
$$

Here $\mathrm{WO}_{3}=$ tungsten oxide, $\mathrm{M}^{+}=$cation injected from electrolyte, $\mathrm{e}^{-}=$electron, $\mathrm{NiO}=$ counter electrode, $\mathrm{Ln}_{2} \mathrm{O}_{3}: \mathrm{Sn}=$ Indium Tin Oxide.

With a $1 / 4$ times [21] reduction of lighting and cooling loads reported makes these windows an indispensable part of the construction architecture. The properties of the electrochromic devices are presented in Table II briefly.

TABLE II. THE PROPERTIES OF ELECTROCHROMIC DEVICES

\begin{tabular}{|l|}
\hline visible - near IR (infrared) $1.0 \%$ to $80 \%$ \\
\hline Switching voltage is $0.5-3.0$ volts \\
\hline Total injected charge up to $50 \mathrm{mc}$ (milli-coulomb) \\
\hline Switching time : $100 \mathrm{~m} \mathrm{sec}$ to $60 \mathrm{sec}(\mathrm{m} \mathrm{sec}=$ milli second) \\
\hline Memory : 1 - 24 hours \\
\hline Cyclic lifetime: $10 \mathrm{~K}-5 \mathrm{M}$ cycles \\
\hline Projected lifetime up to 20 years \\
\hline Operating temperature: $-30^{\circ} \mathrm{c}$ to $70^{\circ} \mathrm{c}(\mathrm{c}=$ temperature) \\
\hline Total thickness of coatings: $\sim 2 \mu(\mu=$ micrometer) \\
\hline Acceptable cost : $100 \$ / \mathrm{m}^{2}$ \\
\hline acceptable neutral color \\
\hline
\end{tabular}

\section{NANOCLAYS}

An increase in density, compressive strength (Right PU foam employing nanoclays exhibit strength of $210 \mathrm{KPa}$ ), young's modulus (4.18 GPa at 5\% loading of nanoclay particle) and tensile strength $(20.8763 \pm 0.789 \mathrm{MPa})$ along with the filling in of air gaps is reported when a combination of ordinary portland cement and nanoclays like metallic nano-kaolin is used and the same is presented in Fig. 2 and Fig. 3, respectively. Detioration of the structures is prevented by the presence of negative charges and separation of layers due to cleavages caused by penetration of water thus leading to an increase in the surface area $\left(700-800 \mathrm{~m}^{2} / \mathrm{gm}\right)$, in the volcanic ash and smectite type clays [24]-[25].

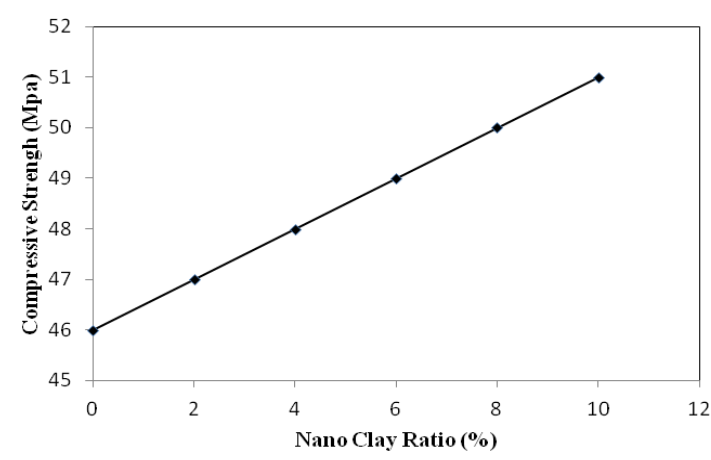

Fig. 2. Compressive strength of NMK mortar hydrated for 28 days.



Fig. 3. Tensile strength of NMK mortar hydrated for 28 days.

\section{SANDVIK NANOFLEX ${ }^{\mathrm{TM}}$}

With a high corrosion resistance, high temperature resistance (Sandvik 12R10/ASTM 302 has a service temperature in range of $-200^{\circ} \mathrm{C}$ to $250^{\circ} \mathrm{C}$ ), high ductility, high tensile strength (1700 MPa-2000 $\mathrm{MPa})$, good responding capability to stress and strain, followed by an occupancy of less area makes Sandvik Nanoflex ${ }^{\mathrm{TM}}$, a stainless steel product developed by Sandvik Materials Technology, a perfect material to be used in fire-proof fixtures and in the doors and windows of a building, thus providing more space and light. Being mechanically strong, chemical and bacteria resistant, recyclable and environment friendly makes this material quite suitable to be incorporated in the construction of sanitary areas and swimming pools [26].

\section{NANOWIRES}

SEM (scanning electron microscope), TEM (transmission electron microscopy) and scanning probe techniques are the means by which nanowires can be classified. The conductance properties, localization effects vary according to the thickness of the material, which also decides on the metal to insulator transition of the nanowires. With an increase in length presence of a higher percentage of metal in the semiconductor carbon matrix is reported which helps us to conclude that above a length of $50 \mathrm{~nm}$ the nanowires behave as metals [27]-[29]. Physical, thermodynamical and electron 
transport properties are dependent on the diameter of the nanowires. Ultraviolet nanowire lasers, bar coding, magnetic information storage are some of the effective optical applications that nanowires like $\mathrm{ZnO}$ (poisson's ratio=0.349) can be put into. Linear or non-linear characteristics are exhibited by the nanowires. By acting as a fuse against higher voltages and currents, nanowires can be an indispensable of the lighting section of construction engineering [30]-[31]. The metal to insulator transition can be calculated by using the following formula [29]:

$$
w(T)=d\left(\ln P^{-1}\right) / d(\ln T)
$$

Here $P=$ resistivity of nanowire, $T=$ temperature, $w(T)=$ width/thickness of the nanowire is a function of temperature i.e. width is dependent on temperature.

\section{TITANIUM DIOXIDE}

TABLE III: THE FOLLOWING ARE THE PROPERTIES OF CRYSTALLINE FORMS

\begin{tabular}{|c|c|c|c|c|}
\hline \multicolumn{5}{|c|}{$\mathrm{OF} \mathrm{TIO}_{2}$} \\
\hline Polymorphs & Rutile & Rutile & Anatase & Anatase \\
\hline & $\| \mathrm{c}$ & -l_c & $\| \mathrm{c}$ & -_c \\
\hline $\begin{array}{c}\text { Crystal } \\
\text { structure }\end{array}$ & Tetragonal & Tetragonal & $\begin{array}{c}\text { tetragona } \\
1 \\
\end{array}$ & tetragonal \\
\hline Space group & $\begin{array}{c}\mathrm{P}_{2} / \mathrm{mnm} \\
(136)\end{array}$ & $\begin{array}{c}\mathrm{P} 4_{2} / \mathrm{mnm} \\
(136)\end{array}$ & $\begin{array}{c}14_{1} / \mathrm{amd} \\
(141)\end{array}$ & $\begin{array}{c}14_{1} / \mathrm{amd} \\
(141)\end{array}$ \\
\hline $\begin{array}{c}\text { Most Stable } \\
\text { State }\end{array}$ & 110 & 110 & 101 & 101 \\
\hline Density & $4.25 \mathrm{~g} / \mathrm{cc}$ & $4.25 \mathrm{~g} / \mathrm{cc}$ & $3.89 \mathrm{~g} / \mathrm{cc}$ & $3.89 \mathrm{~g} / \mathrm{cc}$ \\
\hline $\begin{array}{c}\text { Band gap at } \\
10 \mathrm{~K}\end{array}$ & $3.051 \mathrm{eV}$ & $3.035 \mathrm{eV}$ & $3.46 \mathrm{eV}$ & $3.42 \mathrm{eV}$ \\
\hline $\begin{array}{c}\text { Spectral } \\
\text { Dependence }\end{array}$ & $E^{1 / 2}$ & $\mathrm{E}^{3 / 2}$ & Urbach & \\
\hline Nature of gap & Indirect & Direct & Indirect & Direct \\
\hline $\begin{array}{c}\text { Static } \\
\text { dielectric } \\
\text { constant (in } \\
\text { MHz range) }\end{array}$ & 173 & 89 & 48 & 31 \\
\hline $\begin{array}{c}\text { High } \\
\text { frequency } \\
\text { dielectric } \\
\text { constant } \\
\text { (wavelength= } \\
600 \mathrm{~nm} \text { ) }\end{array}$ & 8.35 & 6.76 & 6.25 & 6.50 \\
\hline $\begin{array}{c}\text { Refractive } \\
\text { index (at } \\
\text { wavelength=6 } \\
00 \mathrm{~nm} \text { ) }\end{array}$ & 2.89 & 2.60 & 2.50 & 2.55 \\
\hline $\begin{array}{l}\text { Nature of } \\
\text { Conductivity } \\
\text { at room } \\
\text { temperature } \\
\text { (undoped) }\end{array}$ & $\begin{array}{c}\text { n-Type } \\
\text { semicondu } \\
\text { ctor }\end{array}$ & $\begin{array}{c}\text { n-Type } \\
\text { semicondu } \\
\text { ctor }\end{array}$ & $\begin{array}{c}\text { n-Type } \\
\text { semicond } \\
\text { uctor }\end{array}$ & $\begin{array}{c}\text { n-Type } \\
\text { semicondu } \\
\text { ctor }\end{array}$ \\
\hline $\begin{array}{c}\text { Mott } \\
\text { transition }\end{array}$ & $\begin{array}{c}\text { Not } \\
\text { Observed } \\
\end{array}$ & $\begin{array}{c}\text { Not } \\
\text { Observed }\end{array}$ & Observed & Observed \\
\hline $\begin{array}{c}\text { Room } \\
\text { Temperature } \\
\text { Mobility in } \\
\text { crystal (in } \\
\mathrm{cm}^{2} / \mathrm{vs} \text { ) } \\
\end{array}$ & $0.1-1$ & $0.1-1$ & 15 & \\
\hline $\begin{array}{c}\text { Room } \\
\text { Temperature } \\
\text { mobility in } \\
\text { polycrystallin } \\
\text { e thin film } \\
\end{array}$ & $\begin{array}{c}0.1 \mathrm{~cm}^{2} / \mathrm{vs} \\
\mathrm{CUA}\end{array}$ & $\begin{array}{c}0.1 \mathrm{~cm}^{2} / \mathrm{vs} \\
\mathrm{CUA}\end{array}$ & $\begin{array}{c}0.1-4 \\
\mathrm{~cm}^{2} / \mathrm{vs}\end{array}$ & \\
\hline $\begin{array}{c}\text { Electron } \\
\text { Effective mass }\end{array}$ & $\begin{array}{l}9-13 \mathrm{~m}_{\mathrm{e}} \\
10-30 \mathrm{~m}_{\mathrm{e}} \\
12-32 \mathrm{~m}_{\mathrm{e}}\end{array}$ & $\begin{array}{l}9-13 \mathrm{~m}_{\mathrm{e}} \\
10-30 \mathrm{~m}_{\mathrm{e}} \\
12-32 \mathrm{~m}_{\mathrm{e}}\end{array}$ & $\sim 1 \mathrm{~m}_{\mathrm{e}}$ & \\
\hline
\end{tabular}

TABLE IV: PROPERTIES OF TITANIUM DIOXIDE CRYSTALLINE FORMS IS AS FOLLOWS:

\begin{tabular}{|c|c|c|c|c|c|c|c|c|}
\hline & $\begin{array}{l}\text { Type } \\
\text { I }\end{array}$ & $\begin{array}{l}\text { Type } \\
\text { II }\end{array}$ & $\begin{array}{l}\text { Typ } \\
\text { e } \\
\text { III }\end{array}$ & $\begin{array}{l}\text { Typ } \\
\text { e IV }\end{array}$ & $\begin{array}{l}\text { Typ } \\
\text { e V }\end{array}$ & $\begin{array}{l}\text { Typ } \\
\text { e VI }\end{array}$ & $\begin{array}{l}\text { Typ } \\
\text { e } \\
\text { VII }\end{array}$ & $\begin{array}{l}\text { AS } \\
\text { TM } \\
\text { Sta } \\
\text { nda } \\
\text { rds }\end{array}$ \\
\hline & $\begin{array}{l}\text { Anat } \\
\text { ase } \\
\text { free } \\
\text { chal } \\
\text { king }\end{array}$ & $\begin{array}{l}\text { Rutile } \\
- \\
\text { low- } \\
\text { medi } \\
\text { um } \\
\text { chalk } \\
\text { resist } \\
\text { ance }\end{array}$ & $\begin{array}{l}\text { Rut } \\
\text { ile- } \\
\text { Me } \\
\text { diu } \\
\text { m } \\
\text { cha } \\
\text { lk } \\
\text { resi } \\
\text { sta } \\
\text { nce }\end{array}$ & $\begin{array}{l}\text { Rut } \\
\text { ile- } \\
\text { Hig } \\
\text { h } \\
\text { cha } \\
\text { lk } \\
\text { resi } \\
\text { sta } \\
\text { nce }\end{array}$ & $\begin{array}{l}\text { Rut } \\
\text { ile- } \\
\text { Hig } \\
\text { h } \\
\text { cha } \\
\text { lk } \\
\text { resi } \\
\text { sta } \\
\text { nce }\end{array}$ & $\begin{array}{l}\text { Rut } \\
\text { ile- } \\
\text { me } \\
\text { diu } \\
\text { m-h } \\
\text { igh } \\
\text { cha } \\
\text { lk } \\
\text { resi } \\
\text { sta } \\
\text { nce }\end{array}$ & $\begin{array}{l}\text { Rut } \\
\text { ile- } \\
\text { me } \\
\text { diu } \\
\text { m-h } \\
\text { igh } \\
\text { cha } \\
\text { lk } \\
\text { resi } \\
\text { sta } \\
\text { nce }\end{array}$ & $\begin{array}{l}\text { D } \\
372 \\
0\end{array}$ \\
\hline $\begin{array}{l}\text { Typic } \\
\text { al end } \\
\text { use } \\
\text { appli } \\
\text { catio } \\
\text { n(S) }\end{array}$ & $\begin{array}{l}\text { Whit } \\
\mathrm{e} \\
\text { exter } \\
\text { ior } \\
\text { hous } \\
\mathrm{e} \\
\text { paint } \\
\text { and } \\
\text { interi } \\
\text { or } \\
\text { uses }\end{array}$ & $\begin{array}{l}\text { Low } \\
\text { mediu } \\
\text { m } \\
\text { perce } \\
\text { nt } \\
\text { PVC }\end{array}$ & $\begin{array}{l}\text { Hig } \\
h \\
\text { perc } \\
\text { ent } \\
\text { PV } \\
\text { C }\end{array}$ & $\begin{array}{l}\text { Ext } \\
\text { erio } \\
\mathrm{r} \\
\text { coat } \\
\text { ings } \\
\text { req } \\
\text { uiri } \\
\text { ng } \\
\text { exc } \\
\text { elle } \\
\text { nt } \\
\text { dur } \\
\text { abil } \\
\text { ity }\end{array}$ & $\begin{array}{l}\text { Ext } \\
\text { erio } \\
\mathrm{r} \\
\text { coat } \\
\text { ings } \\
\text { req } \\
\text { uiri } \\
\text { ng } \\
\text { exc } \\
\text { elle } \\
\text { nt } \\
\text { dur } \\
\text { abil } \\
\text { ity } \\
\text { wit } \\
\text { h } \\
\text { hig } \\
\text { h } \\
\text { glos } \\
\text { s }\end{array}$ & $\begin{array}{l}\text { Inte } \\
\text { rior } \\
- \\
\text { exte } \\
\text { rior } \\
\text { coat } \\
\text { ings } \\
\text { med } \\
\text { ium } \\
\text {-hig } \\
\text { h } \\
\text { perc } \\
\text { ent } \\
\text { PV } \\
\text { C }\end{array}$ & $\begin{array}{l}\text { Inte } \\
\text { rior- } \\
\text { exte } \\
\text { rior } \\
\text { coat } \\
\text { ings } \\
\text { low } \\
\text {-hig } \\
\text { h } \\
\text { perc } \\
\text { ent } \\
\text { PV } \\
\text { C }\end{array}$ & \\
\hline $\begin{array}{l}\mathrm{TiO}_{2}, \\
\text { min, } \\
\%\end{array}$ & 94 & 92 & 80 & 80 & 90 & 90 & 92 & $\begin{array}{l}\mathrm{D} \\
139 \\
4 \\
\end{array}$ \\
\hline $\begin{array}{l}\text { Speci } \\
\text { fic } \\
\text { resist } \\
\text { ance, } \\
\text { min, } \\
\Omega\end{array}$ & 5000 & 5000 & $\begin{array}{l}300 \\
0\end{array}$ & $\begin{array}{l}300 \\
0\end{array}$ & $\begin{array}{l}300 \\
0\end{array}$ & $\begin{array}{l}500 \\
0\end{array}$ & $\begin{array}{l}500 \\
0\end{array}$ & $\begin{array}{l}\mathrm{D} \\
244 \\
8\end{array}$ \\
\hline $\begin{array}{l}\text { Moist } \\
\text { ure } \\
\text { conte } \\
\text { nt as } \\
\text { packe } \\
\text { d, } \\
\text { min, } \\
\%\end{array}$ & 0.7 & 0.7 & 1.5 & 1.5 & 1 & 0.7 & 0.7 & $\begin{array}{l}\mathrm{D} \\
280\end{array}$ \\
\hline $\begin{array}{l}\text { Speci } \\
\text { fic } \\
\text { gravi } \\
\text { ty }\end{array}$ & $\begin{array}{l}3.8-4 \\
.0\end{array}$ & $\begin{array}{l}4.0-4 . \\
3\end{array}$ & $\begin{array}{l}3.6- \\
4.3\end{array}$ & $\begin{array}{l}3.6- \\
4.3\end{array}$ & $\begin{array}{l}3.6- \\
4.3\end{array}$ & $\begin{array}{l}3.6- \\
4.3\end{array}$ & $\begin{array}{l}4.0- \\
4.3\end{array}$ & $\begin{array}{l}\mathrm{D} \\
153\end{array}$ \\
\hline $\begin{array}{l}\text { 45-m } \\
\text { ewm } \\
\text { scree } \\
\text { n } \\
\text { resid } \\
\text { ue, } \\
\text { max, } \\
\%\end{array}$ & 0.1 & 0.1 & 0.1 & 0.1 & 0.1 & 0.1 & 0.1 & $\begin{array}{l}\mathrm{D} \\
185\end{array}$ \\
\hline
\end{tabular}

Anatase, rutile, brookite are some of the crystalline forms in which $\mathrm{TiO}_{2}$ exists in nature. High refraction index is one of the properties of $\mathrm{TiO}_{2}$. When exposed as a coating on the tiles of pavements, concrete, self cleaning glasses, outdoor paints, $\mathrm{TiO}_{2}$ exhibit photocatalysis, whereby on absorption of UV rays electron-hole pair are created, which undergo further reaction to create hydroxyl radicals which oxidize pollutants 
such as oxides of nitrogen into nitrates thus helping to reduce pollution [32]-[35]. The properties of the crystalline form of $\mathrm{TiO}_{2}$ are presented in Table III and Table IV.

\section{NANOCERAMIC COATING}

Being free of dyes and metals coupled with non-interference offered while working with wireless equipments and capability to reject [36] UV rays of sun (temperature resistance $=1200^{\circ} \mathrm{C}$ ), makes shatter proof Huper optik ${ }^{\circledR}$ nanoceramic window films (poisson's ratio = 0.44 for amorphous silicon), the perfect material for lowering cooling loads/bills and improving taste of building.

\section{NANOCRYSTALLINE MATERIALS}

When applied on the construction materials besides enhancing the structural strength of the structures, nanocrystalline coating films made from the likes of materials like nickel, gold, silver and others (possion's ratio for nanocrystalline $\mathrm{Cu}=0.33$ ), also help to reduce corrosion by controlling the oxidation reactions. Varying characteristics like enhanced diffusion, shifting of zero current potential (ZCP), more number of atoms in intercrystalline regions, higher passive current (as in case of nanocrystalline $\mathrm{Ni}$ ) marks a line of difference between properties exhibited by the nanocrystalline materials and their microcrystalline counterparts [37]-[38]. As part of the building materials, for providing of reinforcement and increasing the longevity of paints and varnishes nanocrystalline cellulose can be used [39].

\section{NANOSILICA}

Besides having a low cost (each gram of nanosilica costs 60 paise) budget, high compressive strength (3801 psi), tensile strength $(117.7 \mathrm{MPa})$, high surface area $\left(750 \mathrm{~m}^{2} / \mathrm{gm}\right)$, ability to prevent silicosis, reducing percentage of $\mathrm{CO}_{2}$, nanosilica (particle size $=4-100 \mathrm{~nm}$, colloidal solid percentage $=30 \%$ ) also helps in checking solid waste pollution when mixed with recycled concrete aggregates [40]-[43]. Stress-strain behavior of nanosilica is presented in Fig. 4.

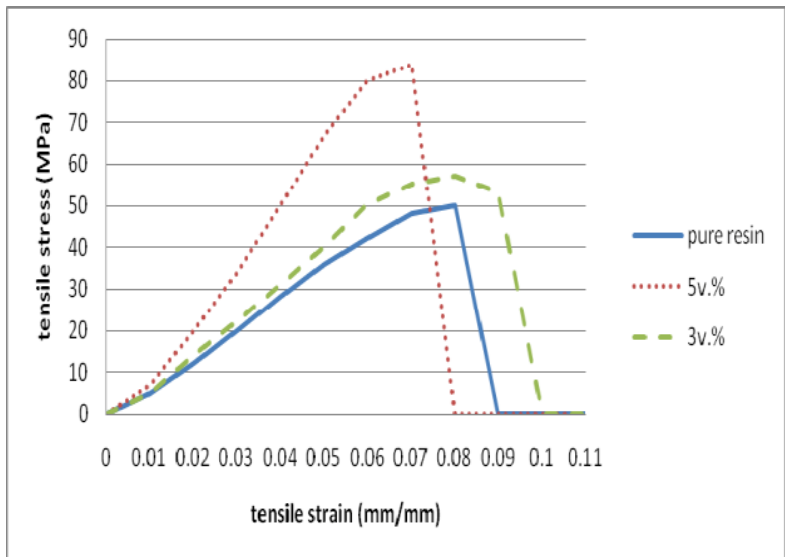

Fig. 4. Stress-strain curves of nanosilica (At a ratio of 70/30 PP matrix/POE containing $5 \%$ wt of $\mathrm{SiO} 2$ exhibited a Young's Modulus of $233+12 \mathrm{MPa}$ or 233-12 MPa).

\section{NANOCOMPOSITES}

Properties like corrosion and temperature resistance (upto $152^{0} \mathrm{C}$ ), providing barrier against entry of gases, thermal conductivity, boosting the flexural and tensile strength (upto $770 \mathrm{MPa}$ ) when used in combination with a polymer, makes nanocomposite materials fit the perfect bill for being used as coatings that are resistant to wear and tear in buildings, erection of columns and decks of bridges and making structural panels [44]-[48]. The stress-strain behavior of the nanocomposite is presented in Fig. 5.



Fig. 5. The above graph illustrates comparison of compressive stress-strain curves at room temperature (a) pure epoxy resin (b) nano composites with cloisite $30 \mathrm{~B}$ (c) nanocomposites with titanium dioxide.

\section{XII. $\mathrm{MMFX}_{2}$ STEEL}

For the construction of bridges desirable properties like, requirement of less steel, higher yield strength, longer lasting, high corrosion resistance, lower maintenance, labor, production, installation costs when compared to conventional carbon steel, keeping a check of growth of micro [49] -galvanic cells by means of a microstructure, are exhibited by a material which goes by the name of $\mathrm{MMFX}_{2}$ steel [49]-[53].

\section{NANOMETALS}

Being light weight, self healing i.e. exhibiting different properties viz. soft or hard, when the need arises, mechanically stronger and more durable when compared to the microscopic particles makes nanometals like nanosilver find application in electrical contacts, indoor insulation purposes of buildings whereas others find application in being parts of circuit boards [54]-[56].

\section{NANOFIBRES}

High temperature withstanding(upto $300^{\circ} \mathrm{C}$ in case of Aramid Nanofibre) insulation (0.96 for $10 \%$ weight of carbon nanofibres put into graphite, other sources say that graphitized ones have a value of 0.0520) services are provided by the nanofibres. Temperatures are brought down in summer by presence of thin film nano-scale stainless steel coatings in masa curtains [57]-[58].

\section{NANOMYTETM MEND MW}

Being free from solvents and volatile organic compounds (VOC) coupled with self healing property makes it desirable 
for using Nanomyte ${ }^{\mathrm{TM}}$ Mend $\mathrm{MW}$ in the construction architecture [59].

\section{NANOCEMENT}

A combination of nanosilica, sodium aluminate, and sodium hydroxide gives nanocement. Reducing carbon-dioxide emissions alongside providing high compressive strength $(50 \%$ replacement of nanocement along with mortar gives strength upto $86.97 \mathrm{~N} / \mathrm{mm}^{2}$ at the end of 21 days) [60]-[61] and avoiding air gaps by virtue of large specific surface area $\left(3582400 \mathrm{~cm}^{2} / \mathrm{gm}\right)$ are some of the properties offered by addition of nanocement to the construction materials. Reduction of penetration of water, filling up air spaces, increasing compressive strength over a prolonged period of time are some of the positive results obtained on mixing nanoparticles like CNT's and composites, in the conventional cement. High magnitudes of tensile and flexular strength that is strong enough to withstand vibrations due to earthquakes with a prolonged longevity coupled with immunity against attack of corrosion, chemicals, penetration of water, is obtained on incorporation of nanocement fibers in the ultra high performance materials [62]-[63].

\section{CONCLUSION}

An extensive literature review was conducted into the properties and applications of nanomaterials that make them useful as a part of the construction materials. This would significantly help the readers such as civil engineers, architects, contractors for quickly getting an idea of the availability of the nanomaterials that can be considered in the design of sustainable and durable structures.

\section{REFERENCES}

[1] R. M. Hlihor and M. Gavrilescu, "Book review of nanomaterials: An introduction to synthesis, properties and application by Dieter Vollath," Environmental Engineering and Management Journal, vol. 7 , no. 6 , pp. $865-870$.

[2] A. K. Rana, S. B Rana, A. Kumari, and V. Kiran. "Significance of nanotechnology in construction engineering," International Journal of Recent Trends in Engineering, vol. 1, no. 4, pp. 46-48.

[3] M. S. Dresselhaus, G. Dresselhaus, J. C. Charlier, and E. Hernández. "Electronic, thermal and mechanical properties of carbon nanotubes," Phil. Trans. R. Soc. Lond, A, vol. 362, pp. 2065-2098, 2004.

[4] P. M. Ajayan and O. Z. Zhou. "Applications of carbon nanotubes," Topics Appl. Phys., vol. 80. pp. 391-425.

[5] E. Skúlason, "Metallic and semiconducting properties of carbon nanotubes," Modern Physics, November 2005.

[6] Z. Hasan, R. Kamran, F. Mohammad, G. Ahmad, and F. Hosein. "Evaluation of different conditions on the mixing bitumen and carbon nano-tubes," IJCEE: International Journal of Civil \& Environmental Engineering, vol. 12, pp. 53-59.

[7] E. Pfautsch, "Challenges in commercializing carbon nanotube composites," Washington Internships for Students of Engineering. (WISE) Journal of Engineering and Public Policy, pp. 1-43.

[8] A. Parviz, "Nano materials in asphalt and tar," Australian Journal of Basic and Applied Sciences, vol. 5, no. 12, pp. 3270-3273.

[9] P. Balaguru and K. Chong, "Nanotechnology and concrete: research opportunities," in Proc. ACI Session on Nanotechnology of Concrete: Recent Developments and Future Perspectives, Denver, USA, 2006, pp. 15-28.

[10] W. J. Chang and H.L. Lee. "Buckling temperature of a single-walled carbon nanotube using nonlocal timoshenko beam model," Journal of
Computational and Theoretical Nanoscience, vol. 7, no. 11, pp. 2367-2371.

[11] J. Seetharamappa, S. Yellappa et al., "The chalkboard, carbon nanotubes: Next generation of electronic materials," The Electrochemical Society Interface, vol. 61, pp. 23-25.

[12] V. A. Sazonova, "A tunable carbon nanotube resonator," Doctor of Philosophy Dissertation, Graduate School of Cornell University, August 2006.

[13] J. Hone, M. Whitney, C. Piskoti, and A. Zettl, "Thermal conductivity of single-walled carbon nanotubes," Rapid Communications. Physical Review B, vol. 59, no. 4, pp. R2514-R2516.

[14] F. Kreupl, "Carbon nanotubes in microelectronic applications," in Advanced Micro \& Nanosystems, Carbon Nanotube Devices, C. Hierold, Ed. Weinheim: WILEY-VCH Verlag GmbH \& Co. KGaA, vol. 8, pp. 1-41, 2008.

[15] K. J. Loh, J. P. Lynch, and N. A. Kotov, "Nanoengineered inductively coupled carbon nanotube wireless strain sensor," presented at the 4th World Conference on Structural Control and Monitoring.

[16] A. Krishnan, E. Dujardin, T. W. Ebbesen, P. N. Yianilos, and M. M. J Treacy. "Young's modulus of single-walled nanotubes," American Physical Society. Physical Review B., vol. 58, no. 20, pp. 14013-14 019 .

[17] N. Sinha and J. T. W. Yeow, "Carbon nanotubes for biomedical applications," IEEE Trans. on Nanobioscience, vol. 4, no. 2, pp. 180-195.

[18] K. T. Kashyap and R. G. Patil, “On young's modulus of multi-walled carbon nanotubes," Indian Academy of Sciences. Bull. Mater. Sci, vol. 31, no. 2, pp. 185-187.

[19] P. Zhao and G. Shi, "Study of poisson's ratios of graphene and single-walled carbon nanotubes based on an improved molecular structural mechanics model," Tech Science Press. SL. vol. 5, no.1, pp. 49-58.

[20] D. A. Licciulli and D. Lisi, "Electrochromic glass," Universitá Degli Studi Di Lecce, Corso di laurea in Ingegneria dei Materiali, A. A. 2001/2002, Scienza e Technologia dei Materiali Ceramici, pp. 1-16.

[21] C. Y. Xu, L. Liu, S. E. Legenski, D. Ning, and M. Taya, "Switchable window based on electrochromic polymers," Materials Research Society. J. Mater. Res, vol. 19, no. 7, pp. 2072-2080.

[22] K. D. Satyen, "Photovoltaic-Integrated electrochromic device for Smart-Window applications," presented at the World Renewable Energy Congress VI Brighton, U. K., July 1-7, 2000.

[23] E. S. Lee, M. Yazdanian, and S. E. Selkowitz, "The energy savings potential of electrochromic windows in the US commercial buildings sector," LBNL-54966, pp. 1-42, April 2004.

[24] M. S. Morsy, S. H. Alsayed, and M. Aqel. "Effect of nano-clay on mechanical properties and microstructure of ordinary portland cement mortar," International Journal of Civil and Environmental Engineering IJCEE-IJEN, vol. 10, no. 1, pp. 23-27.

[25] B. Stiller, "The effect of montmorillonite nanoclay on mechanical and barrier properties of mung bean starch films," M. S. thesis, Dept. Packaging Science, Graduate School of Clemson University, Clemson, South Carolina, United States, 2008.

[26] P. P. Gaspard, "Stainless steel: a superb construction material," presented at the Stainless Steel for Architectural Visions Conference, Paris, France, May 15, 2001.

[27] M. S. Dresselhaus, Y. M. Lin, O. Rabin, M. R. Black, and G Dresselhaus, Nanowires, pp. 1-88, January 2003.

[28] J. I. Pascual, J. Méndez, J. Gómez-Herrero, A. M. Baró, N. Garcia, U. Landman, W. D. Luedtke, E. N. Bogachek, and H. P. Cheng. "Electrical and mechanical properties of metallic nanowires: conductance quantization and localization," American Vacuum Society. J. Vac. Sci. Technol, B., vol. 13, no. 3, pp. 1280-1284.

[29] D. Amalio and F. P. Chicón, "Electrical conduction and magnetic properties of nanoconstrictions and nanowires created by focused electron/ion beam and of $\mathrm{Fe}_{3} \mathrm{O}_{4}$ thin films," Thesis Doctoral, Departamento de Física de la Materia Condensada, Instituto de Nanociencia de Aragón (INA), Instituto de Ciencias de Materiales de Aragón (ICMA), Universidad de Zaragoza- CSIC.

[30] T. Scheibel, R. Parthasarathy, G. Sawicki, X. M. Lin, H. Jaeger, and S. L. Lindquist, "Conducting nanowires built by controlled self-assembly of amyloid fibers and selective metal deposition," PNAS., vol. 100, no. 8, pp. 4527-4532.

[31] Y. Y. Wu, H. Q. Yan, M. Huang, B. Messer, J. H. Song, and P. D. Yang. "Inorganic semiconductor nanowires: rational growth, assembly, and novel properties," Chem. Eur. J. vol. 8, no. 6, pp. 1260-1268.

[32] A. N. Banerjee, "The design, fabrication, and photo catalytic utility of nano tructured semiconductors: focus on $\mathrm{TiO}_{2}$-based nanostructures," 
Dove Press journal: Nanotechnology, Science and Applications, vol. 4 pp. 35-65, 2011.

[33] U. Diebold, "The surface science of titanium dioxide," Science Direct. NH Elsevier. Surface Science Reports, vol. 48, pp. 53-229, 2003.

[34] Dupont ${ }^{\mathrm{TM}}$ ti-pure ${ }^{\circledR}$ titanium dioxide: titanium dioxide for coatings, H-65969-2 (06/07).

[35] M. S. Glass, S. Bhd, and C. Owen, "Self cleaning glass- a better way to keep your windows clean," Iglass News, issue 2, pp. 54-58.

[36] Y. B. Khe, "Cool coatings," Asia Pacific Coatings Journal, vol. 23, no. 4, pp. 36-39.

[37] C. C. Koch, I. A. Ovid'ko, S. Seal, and S. Veprek, Structural Nanocrystalline Materials Fundamentals and Applications, Cambridge University Press, 2007, ch. 6, pp. 319-326.

[38] P. Holister, C. R. Vas, and T. Harper, "Nanocrystalline materials technology white papers nr. 4," Científica, pp. 1-12, October 2003.

[39] I. Oke, "Nanoscience in nature: cellulose nanocrystals," Studies by Undergraduate Researchers at Guelph, vol. 3, no. 2, pp. 77-80.

[40] O. H. Lin, H. M. D. Akil, and Z. A. Mohd Ishak, "Characterization and properties of activated nanosilica/polypropylene composites with coupling agents," Society of Plastics Engineers. Wiley InterScience. Polymer Composites, pp. 1693-1700.

[41] S. Maheswaran, B. Bhuvaneshwari, G. S. Palani, R. Nagesh et al. , "An overview on the influence of nano silica in concrete and a research initiative," Res. J. Recent. Sci., vol. 2, pp. 17-24, ISC-2012.

[42] A. Lázaro and H. J. H. Brouwers, "Nano-silica production by a sustainable process; application in building materials, " presented at the $8^{\text {th }}$ fib PhD Symposium in Kgs., Lyngby, Denmark, June 20-23, 2010.

[43] R. Elansezhian and L. Saravanan, "Effect of nano silica fillers on mechanical and abrasive wear behavior of vinyl ester resin," International Journal of Applied Research in Mechanical Engineering, vol. 1, issue1, pp. 105-108.

[44] Hackman and L. Hollaway, "Polymer-Layered silicate nanocomposites in civil engineering," in Proc. the Second International Conf., University of Surrey, Guildford, UK, 2004, pp. 353-360.

[45] E. W. Gacitua., A. A. Ballerini, and J. W. Zhang, "Polymer nanocomposites: synthetic and natural fillers a revie," Maderas. Ciencia y Tecnología, vol. 7, no. 3, pp. 159-178.

[46] A. Ebrahimpour, "Properties and applications of composites and nanocomposites," PSCI 640 Elements of Nanosciences, November 2009.

[47] S. Bakshi, P. R. Basak, and S. Biswas, "Nanocomposites-technology trends and application potential."

[48] K. M. A. Hossain, "Characteristics of epoxy matrix based composites with various nano-particles," in Proc. the International Conf. on Mechanical Engineering, ICME05-AM-51, Dhaka, Bangladesh, December 2005.

[49] B. E. Sarver, "Mechanical and geometric properties of corrosion resistant reinforcing steel in concrete," M. S. thesis, Dept. Civil Eng., Virginia Polytechnic Institute and State University, Blacksburg, Virginia, 2010.

[50] S. Faza, "The lowest cost construction system high strength and corrosion resistant steel for concrete reinforcement," presented at the Virginia Concrete Conference Bridge Breakout Session, March 11, 2005.

[51] W. B. Geers, "MMFX 2 Reinforcing Steel," presented at Pennsylvania Precast Association Meeting, Pennsylvania, and March 6, 2013.

[52] MMFX Steel Product Guide: MMFX2 Steel Concrete Reinforcing and Pavement Dowel Bars, MMFX Steel Corporation of America, pp. 1-73, June 2007.

[53] Z. Ge and Z. L. Gao, "Applications of nanotechnology and nanomaterials in construction," in Proc. First International Conf. on
Construction In Developing Countries (ICCIDC-I) Advancing and Integrating Construction Education, Research \& Practice, Karachi, Pakistan, 2008, pp. 235-240.

[54] H. Bönnemann and K. S. Nagabhushana, "Advantageous fuel cell catalysts from colloidal nanometals," Journal of New Materials for Electrochemical Systems, vol. 7, pp. 93-108.

[55] J. Pulit, M. Banach, and Z. Kowalsk, "Nanosilver-making difficult decisions," Ecological Chemistry And Engineering S., vol. 18, no. 2, pp. 185-196.

[56] Technical Spotlight: Unique Tools Smooth Jet-Engine Production, Advanced Materials \& Processes, vol. 169, issue 5, pp. 50-51, May 2011.

[57] G. Elvin, "Nanotechnology for green building," Green Technology Forum, 2007.

[58] S. V. Petrik, "Production nanofiber technology- The opportunity for novel materials and their applications," Elmarco Nano for Life, pp. 1-65, June 2010.

[59] R. Delahanty, J. Sloan, M. Musselman, S. Black, D. Brosius, G. Gardiner. M. R. LeGault, P. Malnati, J. Winkel, and K. Wood, "Self healing coating," High Performance Composites, vol. 19, no. 6, pp. $1-64$.

[60] J. Carmichael, M. Prince, and G. Arulraj, "Influence of nano materials on consistency setting time and compressive strength of cement mortar," IRACST-Engineering Science and Technology: An International Journal, ESTIJ, vol. 2, no. 1, pp. 158-162.

[61] B. W. Jo, J. S. Choi, and S. W. Kang, "An experimentation study on the characteristics of chemically synthesized nano-cement for carbon dioxide reduction," Journal of Ceramic Processing Research, vol. 12, no. 3, pp. 294-298.

[62] B. Bhuvaneswari, S. Sasmal, R. Nagesh et al., "Nanoscience to nanotechnology for civil engineering-proof of concepts," Recent Researches in Geography, Geology, Energy, Environment and Biomedicine, pp. 230-235.

[63] L. Raki, J. Beaudoin, R. Alizadeh, J. Makar, and T. Sato, "Cement and concrete nanoscience and nanotechnology," Materials, vol. 3, pp. 918-942.



B. B. Das is currently serving as a senior associate professor and centre head at National Institute of Construction Management and Research (NICMAR), Goa campus. He has been working as a post-doctoral research associate and adjunct professor in the Department of Civil Engineering at Lawrence Technological University, Southfield, Michigan, USA His area of research includes bridge engineering and project management, energy efficiency, green construction management, microstructure characterization of materials, non-destructive testing of concrete structures, corrosion of reinforcement and durability studies on concrete.

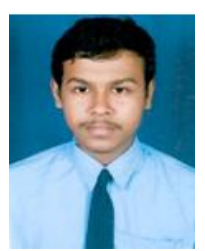

Arkadeep Mitra has successfully furnished his undergraduate studies in electrical engineering from KIIT Deemed University, Bhubaneswar, Odisha. 